\title{
The Attitudes toward Hearing Loss and Hearing Assistive Devices of Students in Education
}

\author{
Ki-Sun Kim'1, Eun-Yeong Shin ${ }^{2}$ \\ 'Departments of Technical Education, ${ }^{2}$ Speech Pathology and Audiology, Sehan University, Yeongam, Korea
}

교육계 재학생의 청력손실과 청각보조장치에 대한 태도

김 기 선 $\cdot$ 신 은 영 ${ }^{2}$

세한대학교 기술교육과', 세한대학교 언어치료청각학과 ${ }^{2}$

\begin{abstract}
Purpose: According to various studies on general education and inclusion education, teachers have a negative attitude towards students with hearing loss. This study provides psychometric evaluation results in regards to the attitudes of students in education who will teach inclusion classes for those with hearing loss. Methods: The 218 students whose major was education related were assessed by using the College Students Attitudes Toward Loss of Hearing Questionnaire designed by Cienkowski \& Pimentel. This questionnaire was composed of fifteen questions with respects to the stigma of hearing loss ( 6 items), knowledge about hearing loss ( 4 items), views of hearing aid (cochlear implant) wearers (5 items), and evaluated people's without hearing disabilities attitude toward of hearing loss. Results: Cronbach's alpha were $0.77-0.79$; indicating high reliability. The percentages of positive awareness about hearing loss were $46.8-$ $97.7 \%$; a somewhat high rate. Attitudes of students in education for hearing loss were decided by studying special education and hearing disability. Conclusion: It was confirmed that students in education had relatively positive attitudes about those with hearing loss which could lead to a change in awareness depending on whether they study special education or deaf education. Currently, teacher education curriculum is insufficient in regards to the understanding of hearing loss. Therefore, it is necessary to strengthen the participation of various teacher training courses and counseling programs to understand hearing loss, and to have proper cooperation with hearing loss specialists.
\end{abstract}

Key Words: Hearing loss, Attitudes, Students in education, Inclusion.

Received: August 22, 2017 / Revised: October 7, 2017 / Accepted: October 17, 2017

Correspondence: Eun-Yeong Shin, Department of Speech Pathology and Audiology, Sehan University, 1113 Noksaek-ro, Samho-eup, Yeongam 58447, Korea Tel: +82-61-469-1483 / Fax: +82-61-469-1317 / E-mail: shiney@sehan.ac.kr

\section{INTRODUCTION}

특수교육대상자란 특수교육을 필요로 하는 사람으로 우리 나라의 특수교육대상자의 수는 2015년에는 88,067명, 2016년 에는 87,950명으로 소폭 감소하였으나, 2011년부터 2016년까지 평균 1,057 명 정도의 폭으로 꾸준히 증가하였다. 또한 특수학 급 수와 특수교원 수도 지속적으로 증가하여 특수교육대상자 의 교육기회 확대 및 지원 서비스가 더욱 강화되고 있는 추세이 다(Ministry of Education, 2016). 특수교육은 특수교육대상자 의 교육적 요구를 충족시키기 위하여 장애 특성에 적합한 교육 과정 및 상담지원·가족지원·치료지원·보조인력지원·보조공학 기기지원·학습보조기기지원·통학지원 및 정보접근지원 등과
같은 특수교육 관련서비스 제공을 통하여 이루어지는 교육을 말한다(Ministry of Education, 2012). 특수교육은 아동의 필요 에 따라 여러 형태로 제공되는데 일반적인 교육 환경에서 볼 때, 일반학급이라는 최소한의 제한적 배치에서 시설에 수용하 는 가장 제한이 큰 배치까지 여러 배치 형태가 하나의 연계적 인 서비스 체계를 이루게 된다. 최근 일반학교에서 제공되는 교 육은 크게 통합교육과 분리교육의 두 가지로 나누고, 일반학급 과 특수학급에서 이루어지는 교육은 통합교육에 포함하고, 특 수학교, 병원, 기숙제 시설에서 이루어지는 교육은 분리교육에 포함한다(Lee \& Park, 2011). 우리나라의 장애인 등에 대한 특 수교육법(2012) 제 2 조 6항에서는 통합교육이란 "특수교육 대상 자가 일반학교에서 장애 유형, 장애 정도에 따라서 차별 받지 아 
니하고 또래와 함께 개개인의 교육적 요구에 적합한 교육을 받 는 것을 말한다”라고 정의하고 있다. 통합교육은 다양한 교육 적 요구와 능력을 가진 아동들이 일반학교에서 함께 교육을 받 는 것으로 성공적인 통합교육을 위해서는 장애 아동과 비장애 아동이 물리적으로 통합하는 것을 넘어 교수적 통합과 사회적 통합을 이룰 수 있도록 상호작용을 할 수 있어야 한다(Choi, 2013; Lee \& Park, 2011; Lee et al., 2015). 통합교육의 기본 원 리는 정상화의 원리(principle of normalization)와 최소제한환 경(least restrictive environment)의 개념이 있다. 정상화의 원 리는 장애인도 정상적인 모든 생활을 위하여 비장애인에게 제 공되는 교육환경과 동일하거나 최대한 유사한 환경에서 교육받 아야 하고, 교육방법 역시 비장애인과 동일하거나 가장 유사한 방법으로 이루어질 수 있도록 모든 기회를 제공해 주어야 한다 는 원리이다. 최소제한환경이란 개념은 장애 아동을 장애가 없 는 또래, 가정, 지역사회로부터 가능한 한 최소한으로 분리시켜 야 한다는 개념으로 이는 물리적인 환경 중심보다는 특수교육 대상자를 위한 서비스 중심이라 할 수 있다. 또한 통합교육의 유형은 완전통합(full inclusion)과 부분통합(partial inclusion), 역통합(reverse inclusion)이 있고, 완전통합이란 학교생활 동안 비장애 아동과 장애 아동이 함께 일반학급에서 같은 환경, 교 육자료, 교사와 함께 수업을 받는 개념이다. 부분통합은 일정 시 간이나 일정 일과에서만 비장애 아동과 장애 아동이 함께 할 수 있는 것으로 개별화된 교육프로그램에 따라 특수학급과 일 반학급을 오가면서 수업을 받는 형태이다. 역통합은 특수학급 에서 비장애 아동과 장애 아동이 일정 시간 동안 활동을 함께 하는 것으로 장애 아동을 위한 프로그램에 비교적 소수의 비 장애 아동을 통합하는 것을 말한다. 최근 완전통합교육은 일반 교육과 특수교육이 협력관계를 형성하고 일반교사와 특수교사 가 함께 노력한다면 일반학급이 모든 장애 아동을 위한 최소제 한환경이 될 수 있다는 생각으로 논의되고 있다. 일반교육과 특 수교육을 재구조화함으로써 완전통합이 이루어진다는 전제 하 에 장애 학생은 새롭게 만들어진 보편적 교육과정으로 일반학 급에서 교육을 받을 수 있도록 노력해야 한다는 개념이다(Choi, 2013; Lee \& Park, 2011).

최근 특수교육대상자의 교육 환경별 배치 현황을 살펴보면 2015년 일반학교에 배치된 특수교육대상자는 61,973명에서 2016년에는 61,989명으로 전체 특수교육대상자 중 70.5\%였고, 특수학교 및 특수교육지원센터에 배치된 특수교육대상자는 2015년에는 26,094명에서 2016년에는 25,961명으로 전체 특수 교육대상자 중 $29.5 \%$ 로 일반학교에 배치된 특수교육대상자의 수의 비율이 매우 크다는 것을 알 수 있다(Ministry of Education, 2016). 특히 청각장애 특수교육대상자는 2016년에는 청각 장애 특수교육대상자 3,401 명 중 일반학교 일반학급 1,816 명
(53.40\%), 일반학교 특수학급 700명(20.58\%), 특수학교 863명 (25.37\%), 특수교육지원센터 22명(0.65\%)으로 조사되었고, 2015년에는 청각장애 특수교육대상자 3,491명 중 일반학교 일 반학급 1,752명(50.19\%), 일반학교 특수학급 765명(21.91\%), 특 수학교 952명(27.27\%), 특수교육지원센터 22명(0.63\%)으로 조 사되어 청각장애 특수교육대상자의 일반학교 배치 비율이 $72.10 \%$ 에서 $73.98 \%$ 로 늘어난 것을 알 수 있다. 청각장애 특수 교육대상자의 일반학급 배치의 비중이 높은 이유는 특수교육 의 통합교육 지향 경향, 신생아청각선별검사의 시행으로 조기 중재와 조기 재활을 통한 언어 발달의 가능성이 높아진 점, 보 청기와 인공와우와 같은 청각보조장치의 개발과 발전, 인공와 우 착용 아동이 늘어나고 있다는 점 등을 들 수 있다(Luckner, 2006). 통합교육은 장애 아동이 일반학급에서 또래와 함께 교 육받게 함으로써 장애에 대한 부정적인 영향의 감소, 장애 아 동뿐 아니라 비장애 아동에게 미치는 학업성취의 향상, 정서 적·발달적 측면과 사회적 상호작용 등의 측면에서 긍정적인 영 향이 보고되고 있다(Idol, 2006; Lee \& Park, 2011; McDonnell et al., 2003; Moon \& Park, 2006; Park \& Kim, 2008). 또 한 통합교육에 대한 장애 아동과 비장애 아동의 부모의 적극적 인 수용 태도와 아동에게 통합교육을 실시하는 교사의 영향 역 시 중요하다. Hallahan et al.(2009)의 완전통합에 대한 정의는 모든 장애 아동이 동네 학교에 배치되어 하루 종일 일반학급에 서 교육받는 것을 의미하고, 일반교사가 장애 아동의 교육에 대 한 우선적인 책임을 진다고 한다. 우리나라의 경우도 청각장애 아동의 통합교육은 일반교육 환경에서 일반교사에 의해 수행된 다(Kim \& Choi, 2009). 일반교사를 위한 특수교육 전문성 및 책무성 강화를 위한 법규에 따르면 교육계 학생들은 교육과정 중 필수 교양으로 '특수교육학' 등을 이수해야 한다. 장애 아동 에 대한 교육이 전체 교육과정 중 한두 과목일 뿐 아니라 특수 교육대상자 중 청각장애 아동의 비중은 $3.9 \%$ 로 상당히 일부이 기 때문에 청각장애 아동을 위한 특별한 교육적 상황에 대한 교육과 인식이 부족할 수 있다.

청력손실과 관련한 인식이나 태도는 대개 설문지를 통해서 측정할 수 있는데, 청력손실에 대한 태도 설문지(Attitudes Towards Loss of Hearing Questionnaire, ALHQ)는 노인성 난청인 의 청력손실의 심리·사회적인 영향을 측정할 수 있다(Sauders \& Cienkowski, 1996). 이는 Brooks(1989)의 72문항의 청력손실 혹은 보청기에 대한 인식(awareness), 사회적인 영향(avoidance, sensitivity, significant other relationship), 적응(acceptance), 부정적 견해(stigma, withdrawal)의 영역을 측정하기 위해 청 력손실에 대한 태도 질문지를 임상적으로 사용하기 유용하도 록 개발한 것이다. 청력손실에 대한 태도 설문지(Sauders \& Cienkowski, 1996)는 청력손실의 사회·정서적 영향(Social and 
Emotional Impact of Hearing Loss, SEI), 청력손실의 부적절한 수용 및 적응(Lack of Acceptance and Adjustment to Hearing Loss, LAA), 가까운 지인으로부터 지지받지 못함에 대한 인지 정도(Perceived Absence of Support from Significant Others, PASSO), 보청기에 대한 부정적 견해(Hearing Aid Stigma, HAS), 청력손실의 인지도(Awareness of Hearing Loss, AHL)로 다 섯 개의 영역을 24 문항으로 측정할 수 있다. 답은 "예 혹은 아니 오”로 답하며, 채점방법을 달리하여 측정 영역에 대한 가중치를 두어 청력손실에 대한 태도를 알 수 있다. 국내에서는 Jo et al. (2011)의 연구를 통해 청력손실에 대한 태도 설문지(Sauders \& Cienkowski, 1996)를 번역하여 난청인의 심리적 평가 도구로 사용할 수 있도록 제안하였다. 일반인을 대상으로 하여 청력손 실에 대한 심리·사회적 태도에 대하여 측정할 수 있는 설문지 로 대학생을 위한 청력손실에 대한 태도 설문지(College Students Attitudes Toward Loss of Hearing Questionnaire, CALHQ)가 있다(Cienkowski \& Pientel, 2001). 이 설문지는 Brooks(1989)의 72문항 중 15문항을 선택하여 청력손실에 대한 부정적 견해(stigma), 청력손실에 대한 지식(knowledge), 보청기 (인공와우) 착용자에 대한 견해[views of hearing aid (cochlear implant) wearers]를 측정할 수 있고, 대학생을 대상으로 하여 청력손실과 보청기에 대한 일반인의 태도를 측정할 수 있었다.

청각장애와 청력손실 및 보청기 착용에 대한 일반인의 인식 과 관련한 국내 연구는 많지 않고, 특히 현장에서 통합교육을 할 수 있는 교육계 학생을 상대로 한 청력손실과 청각보조장치 에 대한 태도조사는 없었다. 본 연구를 통하여 청력손실에 대 한 심리·사회적 태도에 대하여 일반인의 인식을 살펴볼 수 있 는 설문지를 이용하여 추후 통합교육을 책임져야 할 교육계 재 학생을 대상으로 청각장애에 대한 태도를 조사하고자 하였다.

\section{MATERIALS AND METHODS}

\section{연구대상}

설문조사는 세한대학교의 교육계 학과에 재학 중인 218명을 대상(평균 나이: $22.22 \pm 3.23$ 세)으로 모든 대상자의 동의하에 실시하였다(IRB No. SH-IRB 2016-14). 총 3개의 학과에서 응 답하였고, A 학과는 64명(29.4\%), B 학과는 59명(27.1\%), C 학과 는 95명(43.6\%)으로 남학생은 90명(41.3\%), 여학생은 128명 (58.7\%)이었다. 전체 학생 중 1학년은 62명(28.4\%), 2학년은 70명 (32.1\%), 3학년은 49명(22.5\%), 4학년은 37명(17.0\%)이 응답하였 고, 학과별 학년의 분포는 Table 1 과 같다. 응답자 중 현재 혹은 과거에 청력손실이 있거나 보청기(인공와우)를 한 경험이 있는 경우가 전체 218 명 중 2 명이었고, 가족-친척 혹은 가까운 사람 중에 청력손실이 있거나 보청기(인공와우)를 착용한 사람이 있
Table 1. Distribution of grades by major ( $n, \%)$

\begin{tabular}{lccccc}
\hline Major & Grade 1 & Grade 2 & Grade 3 & Grade 4 & Total \\
\hline A & $21(32.8)$ & $17(26.6)$ & $13(20.3)$ & $13(20.3)$ & $64(100.0)$ \\
B & $12(20.3)$ & $21(35.6)$ & $14(23.7)$ & $12(20.3)$ & $59(100.0)$ \\
C & $29(30.5)$ & $32(33.7)$ & $22(23.2)$ & $12(12.6)$ & $95(100.0)$ \\
\hline
\end{tabular}

는 경우는 30명(13.8\%)이었다. 현재 안경이나 콘택트렌즈를 착 용하고 있는 응답자는 121 명(55.5\%)으로 절반 이상이었고, 특 수교육 혹은 청각장애 관련 과목을 수강한 적이 있는 경우는 77명(35.3\%)이었다.

\section{연구방법}

설문조사는 2016년 9 12월 중 실시되었고, 설문지의 응답은 본인이 직접 답을 할 수 있는 형식(paper format)으로 작성하도 록 하였으며 모든 학생은 전체 문항에 답하였다. 대학생을 위 한 청력손실에 대한 태도 설문지(C-ALHQ)는 총 15 문항으로 설문의 원본(Cienkowski \& Pimentel, 2001)을 바탕으로 본 연 구자들이 해석하고 국어과 교수가 검수하여 수정 보완한 것을 사용하였다(Appendix). 원문에는 보청기만을 언급한 반면 본 연구에서는 보청기(인공와우)로 질문하여 특수교육 혹은 청각 장애 관련 교과목을 이수하였을 경우 청각보조장치 중 접할 수 있는 보청기 혹은 인공와우로 교육계 재학생들의 태도를 측 정하기 용이하도록 수정하였고, 일반인이 주체가 되는 13번 문 항은 응답자 본인이 주체가 될 수 있도록 수정하였다. 이는 청 력손실에 대한 부정적 견해와 관련한 5 문항 $(1,3,7,12,14)$, 청 력손실에 대한 지식과 관련한 4 문항 $(4,6,9,11)$, 보청기 착용자 에 대한 견해 6 문항 $(2,5,8,10,13,15)$ 등의 세 가지 영역으로 구성되어 있다. 모든 설문 문항의 답은 “예 혹은 아니오"로 답할 수 있고 설문 작성에 소요시간은 10 분 이내였다. 답의 형태가 “예 혹은 아니오”이지만 “예”가 언제나 긍정적인 답은 아니고, “아니오”도 언제나 부정적인 답은 아니다. 예를 들어, 청력손실에 대한 지식과 관련한 6번 문항인 "보청기(인공와우)는 사람들에 게 큰 도움이 안 된다”에 대한 답은 “아니오”로 답할 경우 긍정적 인 답이라 볼 수 있다. 원본에서 채점한 것과 동일하게 “예”라고 답할 경우 1점, "아니오”라고 답할 경우 0점으로 채점하였다.

\section{자료 분석}

통계분석은 윈도우용 SPSS (version 18.0, SPSS Inc., Chicago, IL, USA) 프로그램을 사용하여 실시하였고, 청력손실에 대한 부정적 견해와 관련한 영역, 청력손실에 대한 지식과 관련 한 영역, 보청기 착용자에 대한 견해와 관련한 영역 및 총점의 기 술통계를 분석하고 신뢰도를 살펴보았다. 본인의 청력손실이 있 거나 보청기(인공와우)를 착용한 경험 유무(experience of hearing loss or hearing aid using in person)를 알아보고자 하였으나 
Table 2. Cronbach's alpha in each item

\begin{tabular}{|c|c|c|c|c|c|c|c|c|c|c|c|c|c|c|c|}
\hline & 1 & 2 & 3 & 4 & 5 & 6 & 7 & 8 & 9 & 10 & 11 & 12 & 13 & 14 & 15 \\
\hline$\alpha$ & 0.79 & 0.79 & 0.78 & 0.78 & 0.78 & 0.79 & 0.79 & 0.79 & 0.79 & 0.79 & 0.78 & 0.79 & 0.77 & 0.78 & 0.79 \\
\hline
\end{tabular}

Table 3. Percentage of subjects in the attitude questionnaire (\%)

\begin{tabular}{ccc}
\hline Items & This study & Cienkowski \& Pimentel(2001) \\
\hline Stigma & & 54.5 \\
1 & 21.1 & 82.8 \\
3 & 72.5 & 23.8 \\
7 & 17.4 & 37.5 \\
12 & 29.4 & 60.0 \\
14 & 68.3 & \\
Knowledge & & 64.0 \\
4 & 47.2 & 2.5 \\
6 & 10.6 & 12.0 \\
9 & 1.8 & 8.0 \\
11 & 18.3 & \\
Views of HA wearers & 4.0 \\
2 & 5.5 & 17.5 \\
5 & 87.2 & 2.5 \\
8 & 10.1 & 10.5 \\
10 & 2.3 & 5.0 \\
13 & 46.8 & 1.0 \\
15 & 2.8 &
\end{tabular}

HA: hearing aids

직접적인 경험을 한 대상자는 2 명 뿐이었으므로 통계에서 제외 하였고, 특수교육 혹은 청각장애 관련 과목 수강 여부(experience of studying about special education), 가족·친척 혹은 가 까운 사람 중에 청력손실이 있거나 보청기(인공와우)를 착용한 경험 유무(experience of hearing loss or hearing aid using in family), 안경이나 콘택트렌즈 착용 유무(experience of using of glasses or contact lens, EG), 성별(gender)에 따른 총점과 세 가지 영역의 차이를 비모수통계인 Welch-Aspin 검정을 통해 유의수준 0.05 미만에서 분석하였다. 또한 학과와 학년에 따른 차이가 있는지 알아보기 위하여 Kluskal-Wallis 비모수 통계를 유의수준 0.05 미만에서 실시하였고, Games-Howell 사후분석 을 실시하였다.

\section{RESULTS}

\section{청력손실에 대한 태도의 신뢰도}

문항의 전반적인 신뢰도는 0.79의 크론바흐 알파(Cronbach's alpha) 값을 보여 비교적 높은 신뢰도를 나타냈고, 문항별로도 0.77 0.79의 신뢰도 계수를 보였다(Table 2).
Table 4. Scores by major

\begin{tabular}{cccc}
\hline & $\mathrm{A}(\mathrm{n}=64)$ & $\mathrm{B}(\mathrm{n}=59)$ & $\mathrm{C}(\mathrm{n}=95)$ \\
\hline Total & $4.77 \pm 1.61$ & $4.20 \pm 1.86$ & $4.31 \pm 2.00$ \\
$\mathrm{~S}$ & $2.30 \pm 0.92$ & $1.88 \pm 1.05$ & $2.07 \pm 1.20$ \\
$\mathrm{~K}$ & $1.70 \pm 0.73$ & $1.58 \pm 0.88$ & $1.42 \pm 0.77$ \\
$\mathrm{~V}$ & $0.77 \pm 0.71$ & $0.75 \pm 0.76$ & $0.81 \pm 0.80$ \\
\hline
\end{tabular}

$\mathrm{S}$ : stigma, K: knowledge, $\mathrm{V}$ : views of hearing aid wearers

\section{청력손실에 대한 태도의 영역별 분포}

청력손실에 대한 부정적 견해와 관련한 5 문항 $(1,3,7,12$, 14), 청력손실에 대한 지식과 관련한 4문항 $(4,6,9,11)$, 보청기 착용자에 대한 견해 6 문항 $(2,5,8,10,13,15)$ 에 대하여 “예” 라 고 답한 대상자의 분포는 Table 3 과 같다. 청력손실에 대한 부 정적인 견해는 3 번 문항[“요즘은 보청기(인공와우)를 착용하더 라도 거의 눈에 띄지 않는다"]과 14번 문항-[만약 보청기(인공 와우)가 더욱 작아진다면 나는 보청기(인공와우) 착용에 거부 감이 없을 것이다"]에 대하여 “예”라고 답한 대상자가 높은 분 포를 보였고, 청력손실에 대한 지식과 관련한 문항 중에서는 4 번 문항[“나는 보청기(인공와우)에 적응하는 데 별 문제가 없을 것 같다"]이 가장 높은 분포를 보였다. 보청기 착용자에 대한 견해의 문항 중에는 5 번 문항[“만약 어떤 사람이 보청기(인공 와우)를 착용하고 있다면, 나는 그 사람이 청각장애라는 것을 알고, 그 사람과 대화할 때 신중하게 배려할 것이다"]이 가장 높은 분포를 보였고, 13번[“청력손실은 노화의 일부이기 때문 에 보청기(인공와우)를 착용하는 것이 두렵지 않다”]이 그 다음 으로 높은 분포를 보였다.

\section{청력손실에 대한 태도의 점수와 대상자의 특성에 따른 차이}

전체 총점은 $4.41 \pm 1.86$ 점이었고, 청력손실에 대한 부정적 견해와 관련한 영역은 $2.09 \pm 1.09$ 점, 청력손실에 대한 지식과 관련한 영역은 $0.78 \pm 0.76$ 점, 보청기 착용자에 대한 견해와 관 련한 영역은 $1.55 \pm 0.79$ 점을 보였고, 총점은 $4.41 \pm 1.87$ 점(최 소 0 점 최대 10점)으로 나타났다. 학과별, 학년에 따른 점수 분 포는 Table 4, Table 5와 같다.

특수교육 혹은 청각장애 관련 과목 수강 여부에 따라 총점 의 유의수준은 0.00 , 청력손실에 대한 부정적 견해와 관련한 영역의 유의수준은 0.046 , 보청기 착용자에 대한 견해와 관련 한 영역의 유의수준은 0.00 으로 유의수준 0.05 미만에서 유의 미한 차이를 보였으나 $(p<0.05)$, 청력손실에 대한 지식과 관련 한 영역에서는 유의수준 0.14 로 유의수준 0.05 미만에서 유의미 한 차이를 보이지 않았다 $(p>0.05)$. 가족·친척 혹은 가까운 
Table 5. Scores by grade

\begin{tabular}{ccccc} 
& $1(\mathrm{n}=62)$ & $2(\mathrm{n}=70)$ & $3(\mathrm{n}=49)$ & $4(\mathrm{n}=37)$ \\
\hline Total & $4.11 \pm 2.01$ & $4.29 \pm 1.90$ & $4.80 \pm 1.68$ & $4.65 \pm 1.72$ \\
$\mathrm{~S}$ & $2.10 \pm 1.21$ & $2.01 \pm 1.07$ & $2.20 \pm 1.06$ & $2.05 \pm 0.97$ \\
$\mathrm{~K}$ & $1.34 \pm 0.75$ & $1.53 \pm 0.81$ & $1.76 \pm 0.83$ & $1.65 \pm 0.72$ \\
$\mathrm{~V}$ & $0.68 \pm 0.74$ & $0.74 \pm 0.81$ & $0.84 \pm 0.69$ & $0.95 \pm 0.78$ \\
\hline
\end{tabular}

$\mathrm{S}$ : stigma, K: knowledge, $\mathrm{V}$ : views of hearing aid wearers

Table 6. Significances by ES, EP, EF, EG, and gender

\begin{tabular}{ccccc}
\hline & ES & EF & EG & Gender \\
\hline Total & $0.000^{*}$ & 0.83 & 0.11 & 0.81 \\
S & $0.046^{*}$ & 0.50 & 0.59 & 0.45 \\
K & $0.140^{*}$ & 0.77 & 0.18 & 0.83 \\
$\mathrm{~V}$ & $0.000^{*}$ & 0.08 & 0.09 & 0.50 \\
\hline
\end{tabular}

${ }^{*} p<0.05$. ES: experience of studying about special education, EF: experience of hearing loss or hearing aid using in family, EG: experience of using of glasses or contact lens, S: stigma, K: knowledge, $\mathrm{V}$ : views of hearing aid wearers

Table 7. Significances by major

\begin{tabular}{clllc}
\hline chi-square & Total & Stigma & Knowledge & $\begin{array}{c}\text { Views of hearing } \\
\text { aid wearers }\end{array}$ \\
df & 2.66 & 4.23 & 0.17 & 5.19 \\
Asymp Sig. & 0.27 & 2 & 2 & 2 \\
\hline
\end{tabular}

사람 중에 청력손실이 있거나 보청기(인공와우)를 착용한 경험 유무, 안경이나 콘택트렌즈 착용 유무, 성별에 따른 총점과 세 영역은 유의수준 0.05 미만에서 유의미한 차이를 보이지 않았 다 $(p>0.05)$ (Table 6).

$\mathrm{A}, \mathrm{B}, \mathrm{C}$ 학과에 따른 총점과 영역별 점수는 유의수준 0.05 미 만에서 유의미한 차이가 없었고 $(p>0.05)$ (Table 7), 1 4학년에 따른 총점과 영역별 점수는 보청기 착용자에 대한 견해와 관련 한 영역에서 유의수준 0.04 로 유의수준 0.05 미만에서 유의미 한 차이를 보였다 $(p>0.05)$ (Table 8). 학년별 차이는 사후분석 결과 1학년과 3학년의 차이 때문인 것으로 나타났다.

\section{DISCUSSIONS}

본 연구는 대학생을 위한 청력손실에 대한 태도 설문지(CALHQ)를 통하여 추후 통합교육을 실시할 수 있는 교육계 재 학생들을 대상으로 청각장애에 대한 태도와 관점을 살펴보고 교사의 역할을 제시하고자 하였다.

본 연구를 통해 청력손실자 본인이 아닌 일반인이 생각하는 청력손실에 대한 부정적 견해, 청력손실에 대한 지식, 보청기 착용자에 대한 견해를 살펴본 것에 본 연구의 의의가 있고, 결 과 역시 청력손실에 대하여 적게는 $46.8 \%$ 에서 많게는 $97.7 \%$ 까
Table 8. Significances by grade

\begin{tabular}{cllcc}
\hline chi-square & Total & Stigma & Knowledge & $\begin{array}{c}\text { Views of hearing } \\
\text { aid wearers }\end{array}$ \\
$\begin{array}{c}\text { df } \\
\text { Asymp Sig. }\end{array}$ & 0.04 & 1.19 & 4.12 & 8.20 \\
\hline${ }^{*} p<0.05$ & & 0.75 & 0.25 & 3 \\
\hline
\end{tabular}

${ }^{*} p<0.05$

지의 분포로 긍정적인 생각을 하고 있다는 것을 살펴볼 수 있 었다. 본 연구에서 사용한 설문지는 문항별 크론바흐 알파 값 이 0.77 0.79의 신뢰도 계수를 보여 신뢰도가 높은 설문지였음 에도 불구하고, 대학생을 위한 청력손실에 대한 태도 설문지의 점수가 높거나 낮다고 하여 보청기에 대해 긍정적인 인식을 갖 고 있는 것이라 말하기 힘들다. 이는 모든 답변에 대하여 이 설 문의 원본(Cienkowski \& Pimentel, 2001)에서 채점한 그대로 “예”라고 답할 경우는 1점, “아니오”라고 답할 경우에는 0점으 로 채점하였기 때문이다. 역문항 채점 방식을 사용하여 질문에 따라 “아니오”로 답했을 경우 긍정적인 답이 될 수 있으므로 1점 을 부여하였더라면, 점수가 높을수록 청력손실에 대한 태도가 긍정적이었다고 말할 수 있을 것이다. 본 연구결과에서 부정적 인 질문 $(1,2,6,7,8,9,10,11,12,15)$ 에 대하여 “예”라고 답하 여 부정적인 태도를 보인 분포가 2.3 29.4\%로 비교적 낮은 편 이었고, 긍정적인 질문 $(3,4,5,13,14)$ 에 대하여 “예”라고 답하 여 긍정적인 태도를 보인 분포는 46.8 87.2\%까지 보였기 때문 에 설문지를 통상적으로 사용하기 위해서는 부정적인 질문에 는 역문항 채점으로 채점 방법을 달리해야 할 것으로 보인다. 부정적으로 묻는 문항에 대하여 “아니오”라고 답하여 긍정적 으로 답변을 한 경우를 살펴보면, 1 번 “나는 다름 사람에게 보 청기(인공와우)가 보일까봐 걱정할 것 같다"는 $78.9 \%, 2$ 번 “보청 기(인공와우)는 노인들만 착용하는 것이다"는 $94.5 \%, 6$ 번 “보청 기(인공와우)는 사람들에게 큰 도움이 안된다"는 $89.4 \%, 7$ 번 “다른 사람이 보청기(인공와우)를 착용하고 있으면 항상 보청기 (인공와우)가 내 눈에 띤다"는 $82.6 \%, 8$ 번 “보청기(인공와우)를 착용한 사람은 청력손실이 없는 사람에 비해 빨리 생각할 수 없다"는 89.9\%, 9번 "젊은 사람은 결코 청각장애가 될 수 없다" 는 98.2\%, 10번 "만약 내가 보청기(인공와우)를 착용한다면 나 를 어리석은 사람으로 생각할 것이다"는 $97.7 \%, 11$ 번 “보청기(인 공와우)를 착용하면 청각장애로 인한 어려움이 완전히 해결될 것이다"는 $81.7 \%, 12$ 번 "내가 보청기(인공와우)를 착용한 것이 보인다고 생각하면 당황스러울 것이다"는 $70.6 \%, 15$ 번 “나는 보청기(인공와우)가 무능력, 어리석음과 관련이 있다고 생각한 다"는 97.2\%로 해당 질문에 대하여 “예”라고 답하는 긍정적인 답의 분포는 $3,4,5,13,14$ 번에 대하여 $72.5,47.2,87.2,46.8$, $68.3 \%$ 로 결론적으로 청력손실에 대해 긍정적인 태도를 보이는 
응답자의 분포는 46.8 97.7\%를 보였다. 또한 청력손실에 대한 지식 영역인 “보청기(인공와우)는 사람에게 큰 도움이 안 된다", "보청기(인공와우)를 착용하면 청각장애로 인한 어려움이 완전 히 해결될 것이다"에 대한 본 연구의 응답 분포가 Cienkowski \& Pimentel(2001)의 응답 분포보다 부정적이었고, 보청기 착용 자에 대한 견해 영역인 "보청기(인공와우)는 노인들만 착용하 는 것이다", "보청기(인공와우)를 착용한 사람은 청력손실이 없 는 사람에 비해 빨리 생각할 수 없다", "나는 보청기(인공와우) 가 무능력, 어리석음과 관련이 있다고 생각한다" 문항에 대하 여 본 연구 결과가 선행연구보다 더 부정적인 응답의 분포가 많았다. 이러한 차이점에 대해서는 유사한 청력손실에 대한 태 도 설문지(ALHQ)의 국내 연구를 통해 유추해 볼 때 심리적 태도의 연구는 사용하는 언어와 문화적 차이, 질문 해석본의 한계점, 우리나라의 정서와 청력손실이 미치는 환경 등일 것으 로 생각한다(Jo et al., 2011).

본 연구 결과 특수교육 혹은 청각장애 관련 과목 수강 여부 가 예비교사의 청력손실에 대한 태도를 결정할 수 있다는 것을 알 수 있었다. 특수교육 혹은 청각장애 관련 과목 수강 여부에 따라 총점, 청력손실에 대한 부정적 견해, 청력손실에 대한 지 식, 보청기 착용자에 대한 견해와 관련한 영역에서 유의수준 0.05 미만에서 차이를 보였고, 보청기 착용자에 대한 견해와 관 련한 영역에서는 학년별 차이를 보였다 $(p<0.05)$. 이러한 학년 에 따른 차이는 사후분석 결과 1학년과 3학년의 차이 때문이었 는데, 교과과정상 3학년 혹은 4학년 때 필수 교직 과목으로 특 수교육 혹은 청각장애 관련 과목을 반드시 한 과목 이상 이수 하도록 되어 있어 이러한 결과의 차이를 보인 것이라 생각한다. 과목 수강 여부와 학년에 따른 차이는 특수교육 혹은 청각장 애 관련 과목을 수강한 경우와 그렇지 않은 경우의 인식의 차 이가 있는 것으로 해석할 수 있어 청각장애 아동과 관련한 교 육의 중요성이 크다고 볼 수 있다. 또한 A, B, C 학과는 특수교 육과 관련이 없는 학과로 본 연구를 통해 학과별 차이가 없는 것은 당연한 결과라고 할 수 있다. 일반교사와 통합교육에 대한 여러 연구들을 통해 볼 때, 일반교사들은 본인 스스로 장애 아 동을 맡을 준비가 되어 있지 않다고 생각하고 장애 아동을 맡 는 것에 대해 부담을 느끼며 통합교육의 이념과 필요성에 대해 서는 긍정적이지만 본인의 실행에 대해서는 부정적인 인식을 가지고 있다. 또한 일반교사들이 장애 아동의 능력이나 특성을 고려하지 못하고 평소 가지고 있는 편견에 의해 부정적인 생각 이나 행동을 하게 되는 경우가 많다고 한다. 이는 장애 아동에 대한 교사의 태도는 교사의 연령, 장애 아동의 지도 경험, 교사 의 전공 분야, 장애에 대한 이해 및 장애 아동 교수에 대한 훈 련 부족, 장애 아동에 대한 부정적인 정서 등이 영향을 받기 때 문이다. 하지만 관련 변인들이 조절 될 경우 교사들의 장애아
동과 통합교육의 실행에 대한 인식과 태도가 긍정적으로 변화 할 수 있다(Choi \& Kang, 2007; Jung \& Seo, 2011; Kim \& Choi, 2009; Oh \& Kim, 2004). 특히 특수교육 관련 교과과정 은 예비유아교사들의 통합교육에 대한 태도를 긍정적으로 변 화시켰다고 보고하고 있고, 통합교육과 관련한 연수교육을 받 은 교사들은 통합교육에 대하여 긍정적인 관점을 갖는다고 하 였다. 대부분의 통합교육에 대한 긍정적인 교사의 태도로 변화 시키기 위한 특수교사와 일반교사의 교육은 대개 행정적·재정 적 지원과 장애의 이해와 장애 아동을 위한 교수적 측면의 방 안을 제시하는 것이다. 하지만 장애 아동 관련 교과목 이수를 통해서 상호작용의 주체로 교사가 장애 아동을 긍정적으로 수 용할 수 있게 되어 교사의 장애 아동에 대한 긍정적 이미지 변 화를 통한 정서적인 변화도 일어난다(Kim \& Choi, 2009; Oh $\& \mathrm{Kim}, 2004)$. 사실 청각장애 아동을 위한 진정한 통합교육이 되기 위해서는 일반교사와 특수교사의 전문성 향상이 보장되 어야 한다(Kim \& Choi, 2009). 현재 예비교사들의 교과과정에 서 현행의 특수교육학개론을 필수 교직 이수로 한 과목을 두고 있으나 사실 한 학기 2시수 혹은 3시수의 수업으로 모든 장애 아동을 이해하기란 쉽지 않을 것이다. 그렇다 하더라도 그 수업 을 통하여 전반적인 장애 아동에 대하여 공부하고, 일정 기간 의 연수과정 시 청각장애 아동의 이해와 청각재활프로그램, 교 실 환경에서의 음향 등에 관한 다양한 주제로 연수 주제를 개 발 및 수업할 필요가 있다. 더불어 청각장애 아동이 통합교육 을 받는 학교의 경우에는 담임교사 및 교과목 담당 교사의 청 각장애의 이해도가 낮을 수 있으므로 별도의 교내 청각장애 이 해 프로그램이 필요하다고 생각한다. 2016년 조사에 의하면, 청 각장애 아동이 통합교육을 받는 비율이 $70.98 \%$ 로 상당히 많은 아동이 통합교육을 받고 있는 실정이다(Ministry of Education, 2016). 하지만 많은 청각장애 아동이 통합교육을 받고 있음에도 청각장애가 전체 장애 아동에서 차지하는 비율은 높지 않기 때문에 소홀해지기 쉬운 것도 사실이다. 청각장애 아동의 보다 효율적인 수업환경과 생활환경 조성을 위하여 관련 전문가들 의 협력적 관계와 다양한 장애의 이해 프로그램 개발이 필요할 것으로 생각한다.

본인뿐 아니라 가족·친척 혹은 가까운 사람 중 청력손실이 있거나 보청기(인공와우)를 착용한 경험 유무, 안경이나 콘택트 렌즈 착용 유무, 성별에 따라 유의미한 차이를 보이지 않았다 $(p>0.05)$. 청력손실에 대해 간접적인 경험이 있는 대상자의 수는 30명으로 비교적 적은 편이었고, 안경이나 콘택트렌즈를 착용하는 대상자는 $55.5 \%$ 로 보청기가 안경이나 콘텍트렌즈와 같이 사회적 수용도가 높지 않아(Heo et al., 2008), 청력손실 에 대한 태도에 차이가 없었던 것으로 여겨진다. 만약 귀걸이형 보청기와 같이 눈에 띄는 보청기를 착용한 상태의 사진이나 인 
공와우를 착용한 사진을 보여준 후 청력손실에 대한 태도를 측 정했다면 결과에 차이를 보였을지도 모른다. 보청기와 인공와 우 착용 사진을 보고 이미지에 대하여 긍정적 혹은 부정적인 형용사를 통한 이미지 평가를 한 결과, 보청기와 인공와우를 착용한 사진의 결과가 보청기와 인공와우를 착용하지 않은 사 진의 결과보다 더 부정적으로 나타났고, 동일 인물에 대해 보청 기와 인공와우를 착용한 조건의 경우, 외모, 성격, 성취가 떨어 지게 보인다는 결과를 보였다(Heo et al., 2008). 대개 일반인들 은 장애에 대해 외형적으로 드러나는 외모, 능력, 사회·경제적 지위 등을 부정적으로 인식하고 판단하는 경향이 있어(Cox et al., 1989), 보청기나 인공와우 착용 시 외부로 드러나는 장치에 대한 일반교사들의 부정적인 선입견이 작용할 수 있다. 하지만 청력손실에 대한 태도는 보청기 사용을 좌우할 수 있고, 개별 맞춤형 상담과 가족과 주변 지인들에 대한 상담을 통해서 긍정 적으로 변할 수 있다(Brooks, 1989). 일반학교에서 통합교육에 적응하지 못하고 회귀한 학생들을 교육하고 있는 청각장애학 교 교사들은 다음과 같이 청각장애 아동의 특성을 설명한다 (Kim \& Choi, 2009). 일반학교에서 교육을 받다가 특수학교에 서 교육을 받게 된 청각장애 아동은 지속적인 무기력 증상을 보여 학습 태도가 전반적으로 수동적이고, 의사소통의 한계로 인하여 특수교육으로 회귀한 경우이므로 교사 또는 또래와 갈 등이 많으며, 사회·정서적으로 매우 불안정하다고 한다. 또한 감정의 기복이 심하고, 건청인에 대한 강한 적개심 혹은 피해의 식, 지나치게 무관심함 등을 보인다고 한다. 교사 연수 프로그 램의 개발 외에도 현재 청각장애 아동 및 가족들이 받을 수 있 는 교내 상담프로그램을 다양화하고, 청각장애 아동에 대한 이 해를 돕기 위하여 청각장애 아동의 통합교육을 맡고 있는 담임 교사 및 교과목 담당교사의 교내 상담프로그램의 참여를 강화 하여야 할 것으로 판단된다.

사실 인공와우 수술 혹은 보청기를 착용한 아동임에도 불구 하고 특수학교에서 교육을 받을 경우 수화를 주된 의사소통으 로 사용하는 경우가 있다. 또한 통합교육에서 수화를 쓰는 청 각장애 아동이 있을 경우, 수화통역사를 통해 수업을 진행을 도울 수 있는 제도가 있으나 실제적으로 활용도는 얼마나 될지 의문이 든다. 현재 "4년제 대학 특수교육 교원 양성과정의 표준 적 모형'에 따른 청각장애교육과 관련된 교과목을 살펴보면 (Kim et al., 2002), 기본이수과목으로 청각장애아교육, 전공심 화에서 청각장애아 음성언어지도, 수화지도, 청각학으로 편성 되어 있으나 전공심화에 대한 실제적인 운영은 전공선택으로 되어 있다. 만약 네 과목을 모두 이수한다고 할지라도 청각장 애학교, 특수학급에서 청각장애학생을 지도해야할 교사의 교 육과정의 교과목으로는 매우 부족하고 현재와 같은 교육과정 운영은 청각장애 아동의 지도를 위한 특수교사의 전문성을 강
화시키기가 어려워 청각장애학교 교사를 위한 청각장애 아동 교육을 이해하기 위한 특별한 교육과정이 필요하다. 더욱이 우 리나라만 세계에서 유일하게 특수교사 자격증에 ‘청각장애' 등 과 같은 특정 장애영역을 표기하지 않는 실정이다(Choi, 2002; Choi, 2008). 우리나라 장애인 등에 대한 특수교육법(2012)에서 명시한 특수교육대상자는 시각장애, 청각장애, 정신지체, 지체 장애, 정서·행동장애, 자폐성장애(이와 관련된 장애 포함), 의사 소통장애, 학습장애, 건강장애, 발달지체, 그밖에 대통령령으로 정하는 장애를 지닌 자 중에서 특수교육을 필요로 하는 사람 으로 진단·평가된 사람을 말한다. 미국의 장애인교육법에서는 장애 아동에 대하여 조금 더 세분화하는 경향이 있어 13 개의 장애로 분류하여, 농(deafness)과 청각장애(hearing impairment)를 구분하고, 농-맹(deaf-blindness), 중복장애와 외상성 뇌손상, 발달지체를 포함한다(Yell et al., 2006). 우리나라의 경 우 청각장애 특수교육대상자는 보청기나 인공와우와 같은 청 각보조장치로 혜택을 볼 수 있는 경우뿐 아니라 수화를 의사 소통 수단으로 사용하는 농을 포함하고 있기 때문에 통합교육 을 논할 때에는 의사소통 수단에 따른 특별한 교육과 안내가 반드시 필요하다.

청각장애 학교 교사들의 인터뷰를 통한 공통적으로 인식하 고 있는 통합교육의 문제점으로 세 가지를 지적하고 있다. 첫 째, 청각장애 통합교육에 대한 명확한 배치 기준이 없어 부모 의 욕구에 의해 무리한 통합교육을 결정하는 경우가 많고, 둘 째, 통합교육 현장에서 청각장애교육을 실천할 수 있는 전문가 가 부족한 실정이다. 사실상 현재 일반교사 양성 체제뿐 아니라 특수교사 양성 체제로는 전문성을 갖춘 청각장애교육을 위한 교사 양성에 한계가 있다. 마지막으로 청각장애 아동의 통합교육 은 청각장애 특성으로 이해되는 특수성을 감안한 청각장애 아 동의 통합교육의 행정적 지원이 필요하다(Kim \& Choi, 2009).

본 연구를 통하여 예비교사들이 청력손실에 대하여 비교적 긍정적인 인식을 가지고 있다는 것을 확인하였고 특수교육 혹 은 청각장애 관련 과목 수강 여부에 따라 인식의 변화를 가져 올 수 있다는 것을 알았다. 본 연구 결과를 바탕으로 보다 더 많은 통합교육 관련 연구를 통하여 추후 청각장애 아동의 진정 한 의미의 완전 통합교육을 위한 기초 자료가 되기를 기대한다.

중심 단어 : 청력손실·태도·교육계 학생·통합교육.

\section{Acknowledgments}

이 논문은 2017년도 세한대학교 교내연구비 지원에 의하여 씨어진 것임.

\section{REFERENCES}

Brooks, D. N. (1989). The effect of attitude on benefit obtained from hearing aids. British Journal of Audiology, 23(1), 3-11. 
Choi, A. K. \& Kang, Y. S. (2007). The image of preservice child-care center teachers' image on children with disabilities. Early Childhood Education Research and Review, 11(3), 27-42.

Choi, K. N. (2013). Inclusive education for young children with disabilities. Audiology, 9(1), 1-6.

Choi, S. K. (2002). Attitudes of the teachers for hearing impaired toward school level based teachers licences for special education. Korean Journal of Special Education, 37(3), 119-141.

Choi, S. K. (2008). Model development on teacher education training with intensive curriculum for deaf school teacher. Journal of Special Education, 15(2), 179-204.

Cienkowski, K. M. \& Pimentel, V. (2001). The hearing aid 'effect' revisited in young adults. British Journal of Audiology, 35(5), 289-295.

Cox, L. R., Cooper, W. A., \& McDade, H. L. (1989). Teachers' perceptions of adolescent girls who wear hearing aids. Language, Speech, and Hearing Services in Schools, 20(4), 372-380.

Hallahan, D. P., Kauffman, J. M., \& Pullen, P. C. (2009). Exceptional Learners: Introduction to Special Education. (11th ed.). Boston, MA: Allyn and Bacon.

Heo, M. J., Kim, L. S., Ahn, S. W., \& Boo, S. H. (2008). Perception and attitude of university students for hearing aid and cochlear implant: hearing aid effect and cochlear implant effect. The Journal of Special Education: Theory and Practice, 9(3), 61-81.

Idol, L. (2006). Toward inclusion of special education students in general education: A program evaluation of eight schools. Remedial and Special Education, 27(2), 77-94.

Jo, B. H., Shin, E. Y., \& Kim, J. S. (2011). A study of validity for psychometric evaluation using Attitude toward Loss of Hearing Questionnaire (ALHQ) for the hearing impaired. Audiology, 7(1), 19-27.

Jung, H. Y. \& Seo, B. S. (2011). A study on image of young children with disabilities recognized by pre-service early childhood teachers. The Journal of Special Children Education, 13(2), 121-149.

Kim, S. A. \& Choi, S. K. (2009). The qualitative research for reality, problems, and future direction on inclusion for students with hearing impairment. The Journal of Special Education: Theory and Practice, 10(4), 471-490.

Kim, Y. W., Kim, D. Y., \& Kim, S. S. (2002). Study on standardized model of training for special education teachers. Korean Journal of Special Education, 37(1), 101-130.
Lee, P. S., Kwon, S. H., Kim, S. J., Kim, S. Y., Park, M. H., Park, S. H., et al. (2015). Understanding and Education of Student with Hearing Loss. (pp. 271-284). Seoul: Hakjisa.

Lee, S. H. \& Park, E. H. (2011). Teaching Exceptional Children in Inclusive Settings. (pp. 12-71). Seoul: Hakjisa.

Luckner, J. (2006). Providing itinerant services. In D. F. Moores \& D. S. Martin. Deaf Learners: Developments in Curriculum and Instruction. Washington DC: Gallaudet University Press.

Ministry of Education. (2017, June 29). Special education laws for persons with disabilities and others. Retrieved from http://www.law.go.kr/lsInfoP.do?lsiSeq=183510\&efYd=20170530\#0000.

Ministry of Education. (2017, June 29). 2016 Special Education Annual Report. Ministry of Educaion. Retrieved from http://moe.go.kr/boardCnts/ view.do?boardID $=319 \&$ boardSeq $=64226 \& l e v=0 \&$ searchType $=$ null\&st atusYN $=W \&$ page $=1 \& s=$ moe $\& m=030208 \&$ opType $=N$.

Mcdonnell, J., Thorson, N., Disher, S., Mathot-Buckner, C., Mendel, J., \& Ray, L. (2003). The achievement of students with developmental disabilities and their peers without disabilities in inclusive settings: An exploratory study. Education and Treatment of Children, 26(3), 224-236.

Moon, J. O. \& Park, J. Y. (2006). Effects of a disability-awareness program during homeroom classes on the attitudes of the highschool students toward individuals with disabilities. Special Education Research, 5(1), 51-72.

Oh, Y. H. \& Kim, H. J. (2004). The effects of special education related curriculum on pre-service early childhood teachers' attitudes toward inclusion education for disabled children. Journal of Humanities, 21, 95110.

Park, M. H. \& Kim, S. Y. (2008). The effectiveness of a classwide peer network program on the friendship between children with and without disabilities and general children's attitudes toward disabled people. Special Education Research, 7(1), 51-71.

Saunders, G. H. \& Cienkowski, K. M. (1996). Refinement and psychometric evaluation of the attitudes toward loss of hearing questionnaire. Ear and Hearing, 17(6), 505-519.

Yell, M. L., Shriner, J. G., \& Katsiyannis, A. (2006). Individuals with disabilities education improvement act of 2004 and IDEA regulations of 2006: Implications for educators, administrators, and teacher trainers. Focus on Exceptional Children, 39(1), 1-24. 


\section{APPENDIX $\square$}

\section{College Students' Attitudes toward Loss of Hearing Questionnaire}

해당 사항에 표시해 주세요.

\begin{tabular}{|c|c|c|c|c|}
\hline 학 년 & 1학년 & 2학년 & 3학년 & 4학년 \\
\hline 성 별 & 남 & 여 & \\
\hline 나 이 & & 학과 & \\
\hline
\end{tabular}

\begin{tabular}{|l|l|l|}
\hline 나는 현재 혹은 과거에 청력손실이 있거나 보청기(인공와우)를 한 경험이 있다. & 예 & 아니오 \\
\hline 가족, 친척 혹은 가까운 사람 중에 청력손실이 있거나 보청기(인공와우)를 착용한 사람이 있다. & 예 & 아니오 \\
\hline 나는 안경이나 콘택트렌즈를 착용하고 있다. & 예 & 아니오 \\
\hline 나는 특수교육 혹은 청각장애 관련 과목을 수강한 적이 있다. & 예 & 아니오 \\
\hline
\end{tabular}

※ 현재 본인의 생각이나 감정에 가장 적합한 답변에 동그라미 하세요.

\begin{tabular}{|c|c|c|c|}
\hline 1 & 나는 다른 사람에게 보청기(인공와우)가 보일까봐 걱정할 것 같다. & 예 & 아니오 \\
\hline 2 & 보청기(인공와우)는 노인들만 착용하는 것이다. & 예 & 아니오 \\
\hline 3 & 요즘은 보청기(인공와우)를 착용하더라도 거의 눈에 띄지 않는다. & 예 & 아니오 \\
\hline 4 & 나는 보청기(인공와우)에 적응하는 데 별 문제가 없을 것 같다. & 예 & 아니오 \\
\hline 5 & $\begin{array}{l}\text { 만약 어떤 사람이 보청기(인공와우)를 착용하고 있다면, 나는 그 사람이 청각장애라는 것을 알고, } \\
\text { 그 사람과 대화할 때 신중하게 배려할 것이다. }\end{array}$ & 예 & 아니오 \\
\hline 6 & 보청기(인공와우)는 사람들에게 큰 도움이 안 된다. & 예 & 아니오 \\
\hline 7 & 다른 사람이 보청기(인공와우)를 착용하고 있으면 항상 보청기(인공와우)가 내 눈에 띤다. & 예 & 아니오 \\
\hline 8 & 보청기(인공와우)를 착용한 사람은 청력손실이 없는 사람에 비해 빨리 생각할 수 없다. & 예 & 아니오 \\
\hline 9 & 젊은 사람은 결코 청각장애가 될 수 없다. & 예 & 아니오 \\
\hline 10 & 만약 내가 보청기(인공와우)를 착용한다면 나를 어리석은 사람으로 생각할 것이다. & 예 & 아니오 \\
\hline 11 & 보청기(인공와우)를 착용하면 청각장애로 인한 어려움이 완전히 해결될 것이다. & 예 & 아니오 \\
\hline 12 & 내가 보청기(인공와우)를 착용한 것이 보인다고 생각하면 당황스러울 것이다. & 예 & 아니오 \\
\hline 13 & 청력손실은 노화의 일부이기 때문에 보청기(인공와우)를 착용하는 것이 두렵지 않다. & 예 & 아니오 \\
\hline 14 & 만약 보청기(인공와우)가 더욱 작아진다면 나는 보청기(인공와우) 착용에 거부감이 없을 것이다. & 예 & 아니오 \\
\hline 15 & 나는 보청기(인공와우)가 무능력, 어리석음과 관련이 있다고 생각한다. & 예 & 아니오 \\
\hline
\end{tabular}

This questionnaire was written with reference to the Cienkowski \& Pimentel(2001) paper. 